\title{
Gravity process foundry simulation
}

\section{Simulación del proceso de fundición a gravedad}

\author{
CERRITO-TOVAR, Ivan de Jesus $\dagger^{* \prime *}$, VALDES-MEDRANO, Adriana Paulina”’, GARCIA-DUARTE, \\ Oscar Enrique' and HUERTA-GÁMEZ, Héctor'
}

Universidad Politécnica de Juventino Rosas. Automotive Systems Engineering Career. Hidalgo 102, Community of Valencia, Juventino Rosas, Gto, Mexico.

"Brovedani Reme México. Avenida Industria de la Construcción 411, 76130 Querétaro, Qro.

ID $1^{\text {st }}$ Author: Ivan de Jesus, Cerrito-Tovar / ORC ID: 0000-0002-8601-9911

ID $1^{\text {st }}$ Co-author: Adriana Paulina, Valdes-Medrano / ORC ID: 0000-0003-1867-2510

ID $2^{\text {nd }}$ Co-author: Oscar Enrique, Garcia-Duarte / ORC ID: 0000-0002-4781-8438

ID $3^{\text {rd }}$ Co-author: Héctor, Huerta-Gámez / ORC ID: 0000-0002-5088-310X

DOI: $10.35429 / \mathrm{JCS} .2021 .13 .5 .8 .14$

Received: January 15, 2021; Accepted June 30, 2021

\begin{abstract}
In this work, they going to use a foundry simulation software to compare the virtual vs real results and try to reduce the time of the real process in the foundry area. In the real process they work with the re-engineering process of the pistons, first they take the original element and take the physical properties (length, width, thicknesses, etc.), after make a cast design and is assigned some parameters for the process, planning the process to make a test, after the casting process it goes to the machining process and finally the final inspection says if all the process during the tests is correct, if not, we need to take others parameters or casting design. With this project is going to be possible to save time in the foundry area and make a virtual process to see the result and change all the necessary things to have a perfect process
\end{abstract}

\section{Resumen}

Éste trabajo utilizará un software de simulación de fundición para hacer una comparación entre resultado virtual y real del proceso de fundición para tratar de reducir los tiempos del proceso en el área. En el proceso real se realiza a través de la reingeniería en la fabricación de pistones, primeramente se es tomado el pistón original con sus respectivas propiedades físicas (longitudes, espesores, ancho, etc.), después se realiza un proceso de diseño del molde y se le son asignados parámetros para su proceso en piso, se planea el proceso para realizar una prueba en producción, después de que se lleva a cabo dicha prueba, pasa al área de maquinado para después ser inspeccionado en la línea y determinar si las condiciones del diseño contra las reales en piso fueron correctas, si no, se necesita tomar nuevos parámetros basándose en los resultados para una nueva prueba. Con éste proyecto será posible ahorrar tiempo en fundición ya que el proceso virtual ayudará a saber el resultado antes de que se lleve a cabo en piso y así de ese modo poder trabajar con los parámetros correctos para tener un producto sin defectos.

Fundición, Pistón, Proceso de simulación

Citation: CERRITO-TOVAR, Ivan de Jesus, VALDES-MEDRANO, Adriana Paulina, GARCIA-DUARTE, Oscar Enrique and HUERTA-GÁMEZ, Héctor. Gravity process foundry simulation. Journal Computational Simulation. 2021. 5-13:8-14.

\footnotetext{
* Correspondence to the author (Email: icerrito_ptc@upjr.edu.mx)

$\dagger$ Researcher contributing as first author.
} 


\section{Introduction}

The pistons are manufactured mostly through the aluminum gravity casting process, for that reason, you must have correct parameters in your process and avoid defects that can be caused by a misallocation of the same, the defects are divided in 2 branches, natural variations and parameter variations, the former are difficult to control externally, but can have immediate corrections in the process. Parameter variations are entirely the responsibility of the process and mold design, therefore, a correct assignment of them will eliminate this variation.

With the process that was proposed for the design prior to the launch of a new product, the process will be simulated in a virtual way with the first parameters that are thought to help the process correctly, if they are not favorable, the software will indicate its results. In this way, we will be able to assign or adjust the parameters previously proposed, in such a way that the process will be simulated as many times as necessary until the expected result is reached.

The defects that appear have their possible causes and if any defect of this type appears, new parameters will have to be assigned (time, temperatures, internal design, etc.) to carry out the process and obtain a piece free of imperfections, this type of arrangement the process can take from 2 weeks to 6 months. Consequently, time and material are wasted in what is reached a suitable time or more approximate to what would be a successful process, which ideally consists of the shortest possible time to carry out solidification and at the end of this that the piece is free of blemishes.

By using the software it is intended to understand and analyze how it will behave in the conditions with which it is worked when it is molded, in this way to know and predict areas of porosity and correct filling times to obtain a clean molded part.

\section{Establishment of the Project}

In the first part of the project, it was to carry out a simulation test on an existing part number within the company, which already has a bad history in terms of defects, that is, it is already a product that is made on the floor but always had scrap complications, based on any number of defects that had occurred and due to having derived from the casting process, a defect that was considered the most recurrent in this part number was the pores in the piston head, this defect, for more that they moved and changed parameters on the floor, it was never successful in correcting such a defect, therefore, it is a litmus test for the reliability of the software, that is, the piston will be analyzed in such software and the result we need obtain will be a piston with the most reminiscent defect in the mechanical element, if the result in this case is favorable, that is, it comes out with the defect shown, the parameters will be changed virtually until a result is obtained favorable casting, that is, without defects.

Afterwards, a test will be carried out on the floor to compare and verify virtual vs real, in such a way the reliability of the program will be demonstrated and verified and if this turns out as planned, it will be passed to a second stage that will be with a new product to establish to its new conditions before doing the process on the floor. For this, companies in the automotive sector have worked to improve casting processes [1]. The aforementioned process is represented in figure 1 .

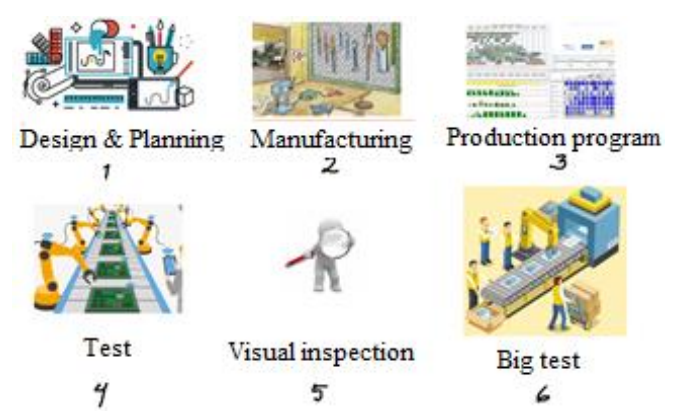

Figure 1 Re-engineering process in the company

The defects in casting are infinite, but with their respective reason for being, therefore, each defect is different from each other as much as its solution [2], the piston of the so-called reliability test for the most part or the most critical defect it is "head pore" as it sounds it is a hole in the head of the element as shown in Figure 2. 


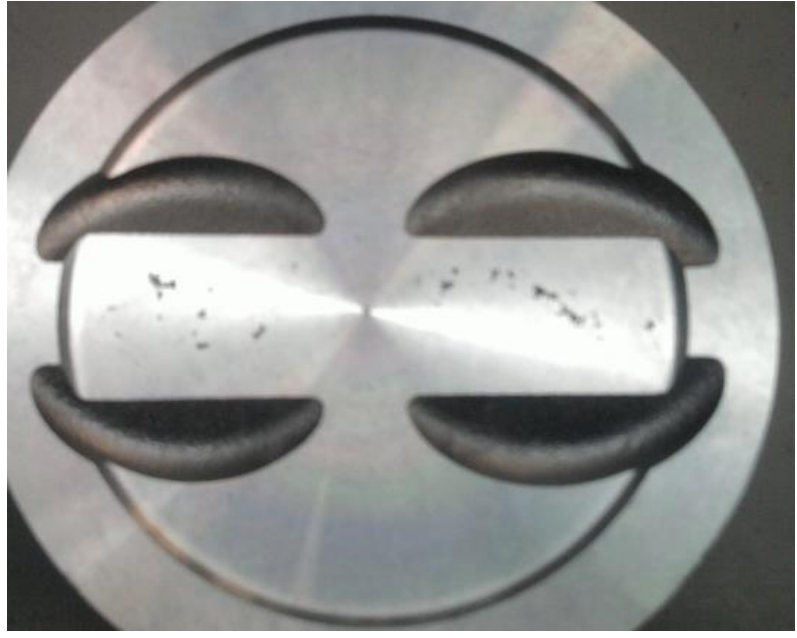

Figure 2 Pore in the head of a piston

From a production of 2000 pieces of such part number, a description was made of its defects and their percentages which are shown in table 1 .

\begin{tabular}{|l|r|r|}
\hline \multicolumn{1}{|c|}{ Default } & N. Pieces & Percentage \\
\hline Gas & 250 & $25 \%$ \\
\hline Pore in head & 500 & $50 \%$ \\
\hline Cold junction & 100 & $10 \%$ \\
\hline Not filled & 50 & $5 \%$ \\
\hline Metallic inclusion & 100 & $10 \%$ \\
\hline
\end{tabular}

Table 1 Description of the defects of a production run

The part number used for its demonstration has a performance of $50 \%$, that is, of the manufactured parts derived from its low performance, half will always be considered scrap as shown in the production identified in the previous Table.

\section{Development of the methodology to obtain parameters}

As described at the beginning, to obtain the parameters to work on the floor, the current process is to compare a piston that has similar characteristics (size, alloy, model, etc.) in order to copy and adjust the parameters and obtain similar results to a product with a high yield (greater than 85\%), therefore, the parameters shown in Table 2 are the ones with which the part number is currently being worked on the floor and even so there is a very high yield. low (50\%), in such a way that they have been modified several times and it has not been possible to reduce the scrpa of said product.

\begin{tabular}{|l|r|}
\hline \multicolumn{2}{|c|}{ Solidification parameters } \\
\hline Mold temperature & $430^{\circ} \mathrm{C}$ \\
\hline Metal temperature & $750^{\circ} \mathrm{C}$ \\
\hline Outside temperature & $25^{\circ} \mathrm{C}$ \\
\hline RH & $25 \%$ \\
\hline Solidification time & $85 \mathrm{~s}$ \\
\hline Cooling fluid & Water \\
\hline
\end{tabular}

Table 2 Solidification parameters

Based on these parameters, we will proceed to simulate in the software using the CAD models of the piston and the mold, to later use these parameters and obtain the desired results.

\section{Obtaining the CAD model and assembly of the mold}

Due to the current technological conditions for the standards of the companies, there are constant changes on the pieces, these changes must be reflected in the documents that support the elements, for that reason the way of working is through CAD software with which they make the 3D pieces and after that they generate the plans that will later support their manufacture, therefore, when making a modification or improvement of it, it is carried out directly on the $3 \mathrm{D}$ piece and automatically a change is generated in the plane [3], now logically this will be the new plane already with the modification. Therefore, the CAD parts of the part and the mold were obtained as the complete part was designed (piston and casting mold) as can be seen in Figure 3.

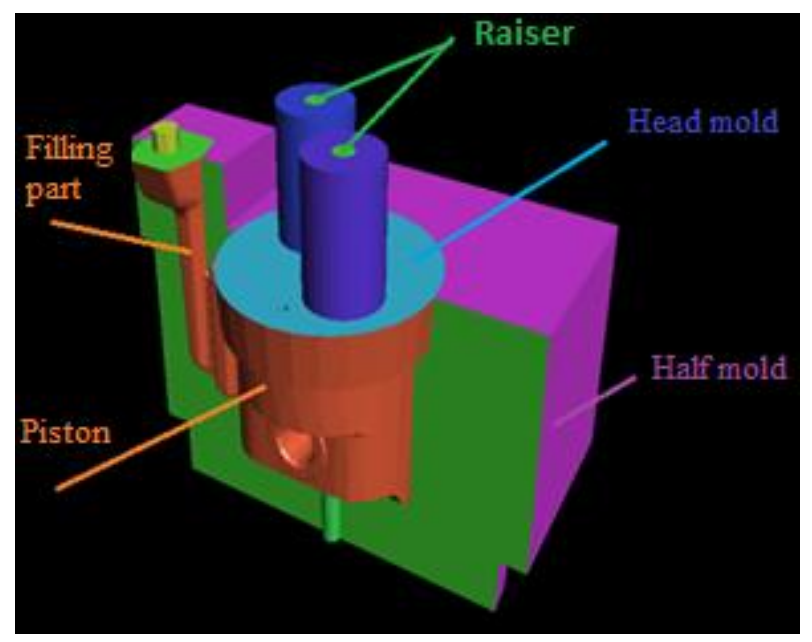

Figure 3 Piston and mold for casting (assembly) 
Once the assembly is finished, it must be checked that the export of the CAD model does not have out of place geometries, that is, the virtual assembly must remain as the real one, for this there is a tool in the software that is responsible for detecting some geometry irregular or something that could affect us in the simulation.

If they do exist, the same software gives you the option to correct automatically as shown in Figure 4, if there are no discrepancies in the software, it sends you a message that the simulation can be started.
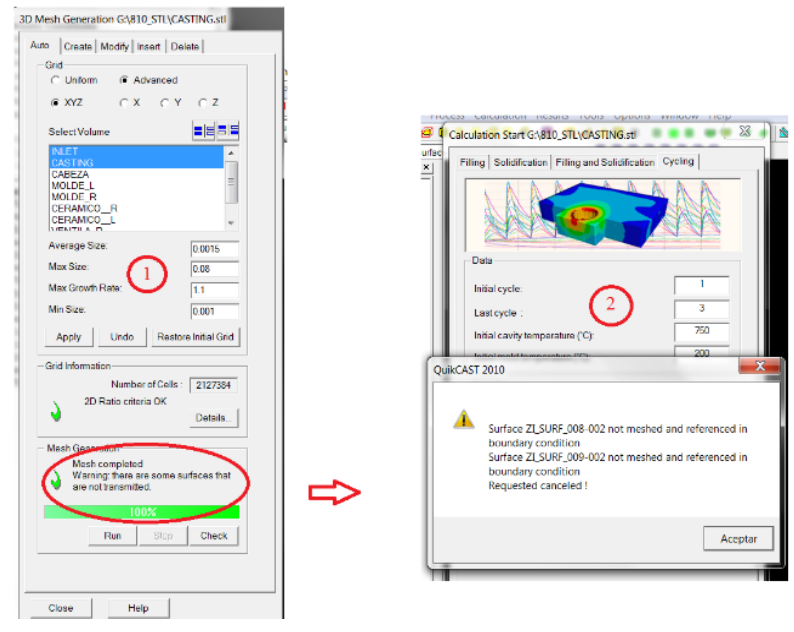

Figure 4 Export problems message

\section{Piston alloy to simulate}

In the company 3 types of alloys are used, derived from this, the mechanical and thermal properties change depending on it, for that reason, it is necessary to place the percentages within the software so that the results are the most approximate to reality depending on their chemical composition elements as shown in Table 2 .

The elements that make up the alloy to be oxidized are shown in Table 2 in which the alloy contains $8.5-10.5 \%$ silicon.

\begin{tabular}{|c|c|c|c|}
\hline Element & M-124 & F-132 & AS-17 \\
\hline$\% \mathrm{Si}$ & $11.00-13.00$ & $8.5-10.5$ & $15-16$ \\
\hline$\% \mathrm{Fe}$ & $0.7 \max$ & $1.00 \max$ & $0.7 \max$ \\
\hline$\% \mathrm{Cu}$ & $0.8-1.3$ & $2.0-4.0$ & $2.0-3.0$ \\
\hline$\% \mathrm{Mn}$ & $0.3 \max$ & $0.5 \max$ & $0.4 \max$ \\
\hline$\% \mathrm{Mg}$ & $0.8-1.3$ & $0.5-1.50$ & $0.5-1.0$ \\
\hline$\% \mathrm{Ni}$ & $0.8-1.3$ & $0.5 \max$ & $0.35-0.80$ \\
\hline$\% \mathrm{Zn}$ & $0.3 \max$ & $1.00 \max$ & $0.030 \mathrm{max}$ \\
\hline$\% \mathrm{Ti}$ & $0.2 \max$ & $0.25 \max$ & 0.2 \\
\hline$\% \mathrm{Ca}$ & $0.007 \max$ & $0.007 \max$ & $0.007 \max$ \\
\hline
\end{tabular}

Table 2 F-132 alloy elements
According to these elements, the alloy is registered with its different percentages within the program as shown in figure 5, it is only the alloy to be cast, because the molds are made of cast iron and the same software it already has the parameters established in its memory, therefore, its effect within the similar foundry is already taken into account for its possible effects.

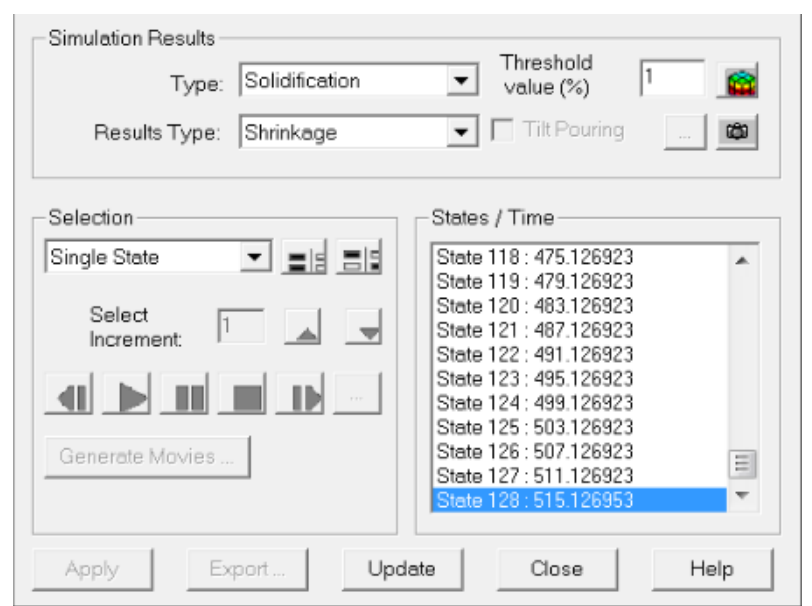

Figure 5 Alloy to be used in simulation

Once the base parameters have been established within the program, we proceed to indicate each of the elements and place their boundary condition (Figure 6).

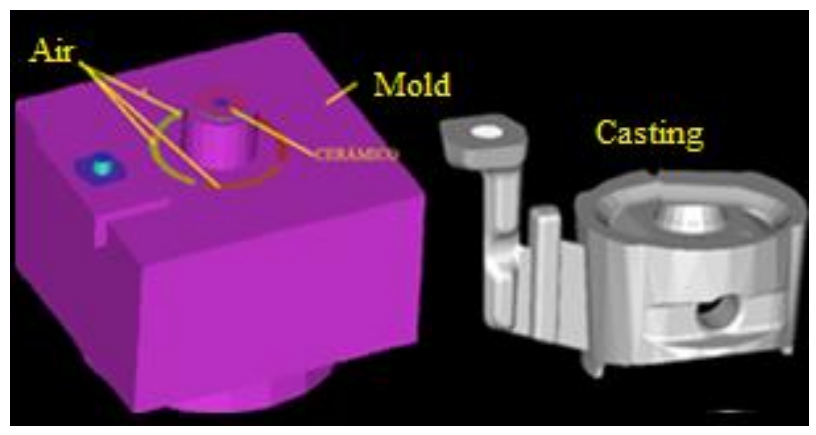

Figure 6 Selection of parts for material assignment

\section{Simulation and results (Software)}

Once the data has been emptied into the software and having the assembly free of imperfections within its export [4], the simulation is run with the established parameters (Figure 7). 


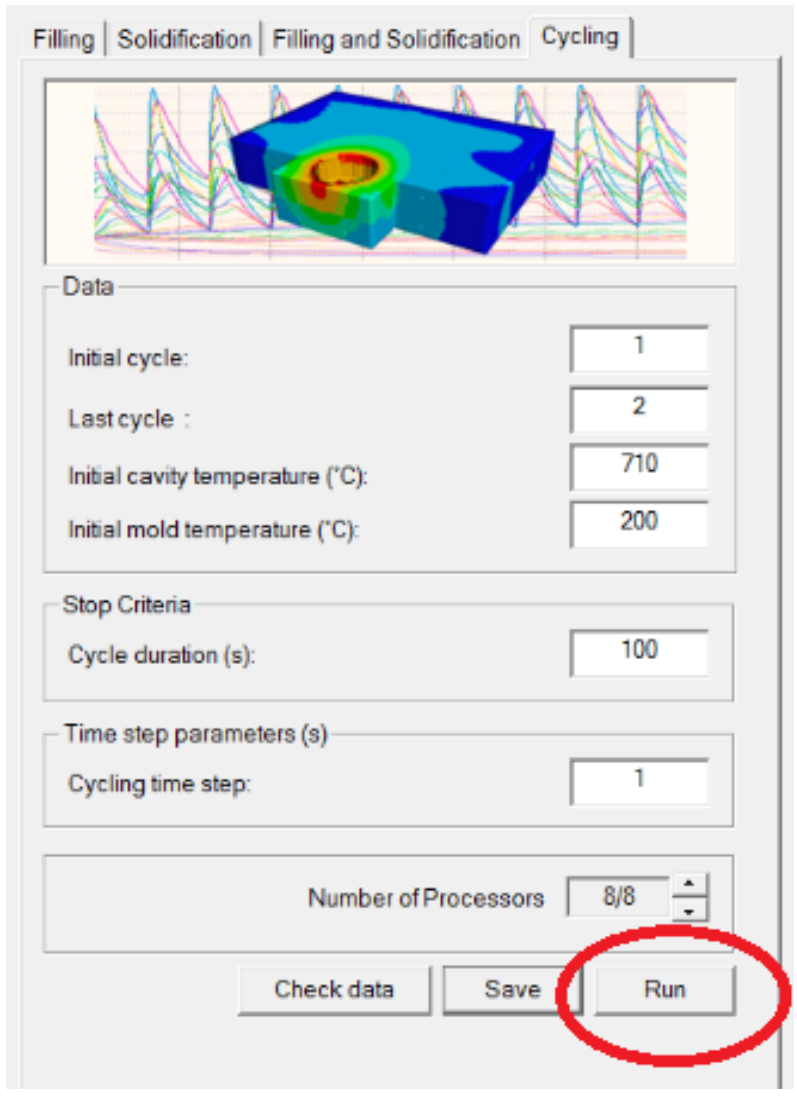

Figure 7 Simulation start

As a result, a transparent part is shown with possible defects in another color to make a contrast and identify possible defects more clearly as shown in Figure 8.

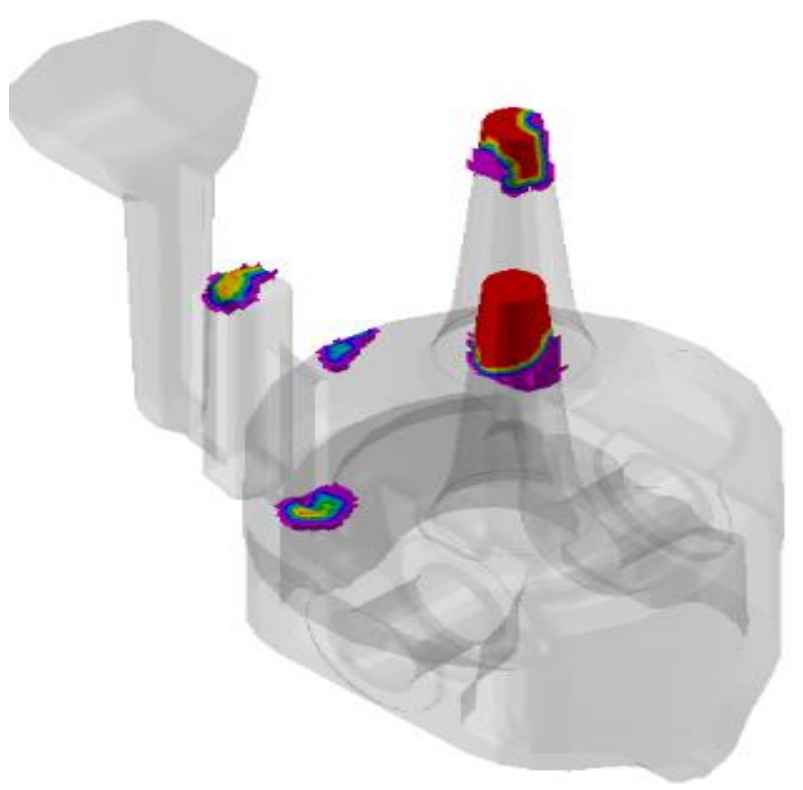

Figure 8 Simulation result with initial parameters

The defects, as previously explained, are shown in another color and are the result of virtual casting with the parameters established on the floor. As indicated with this part number, there were $50 \%$ defects due to "pore in the head" as the simulation showed it and is shown in Figure 9.

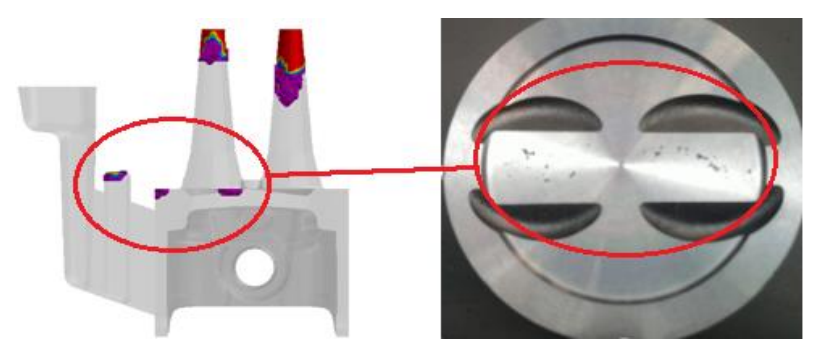

Figure 9 Piston with defective head

Once it has been demonstrated that the software is throwing us the probelam that is supposed to be greater in our performance of the element, we have to analyze the design of the mold for the piston, because it can clearly be seen that the defect is due to the variation of the piston. design of the process and not of external functions, since the software encapsulates the conditions by design in the results.

\section{New piston design and simulation}

Derived from the result that the simulation yielded and when corroborating the defect that was presented above on the floor, the design was analyzed and it was decided to change the design of the piston feed (riser) since it was deduced that having 2 risers kept too much heat As a result of this, there was a bad distribution of the metal in the piston head, for that reason the "pore" was having, therefore, a piston with a single riser was designed and placed at the beginning of the piston, to help its distribution and help its solidification as shown in Figure 10.

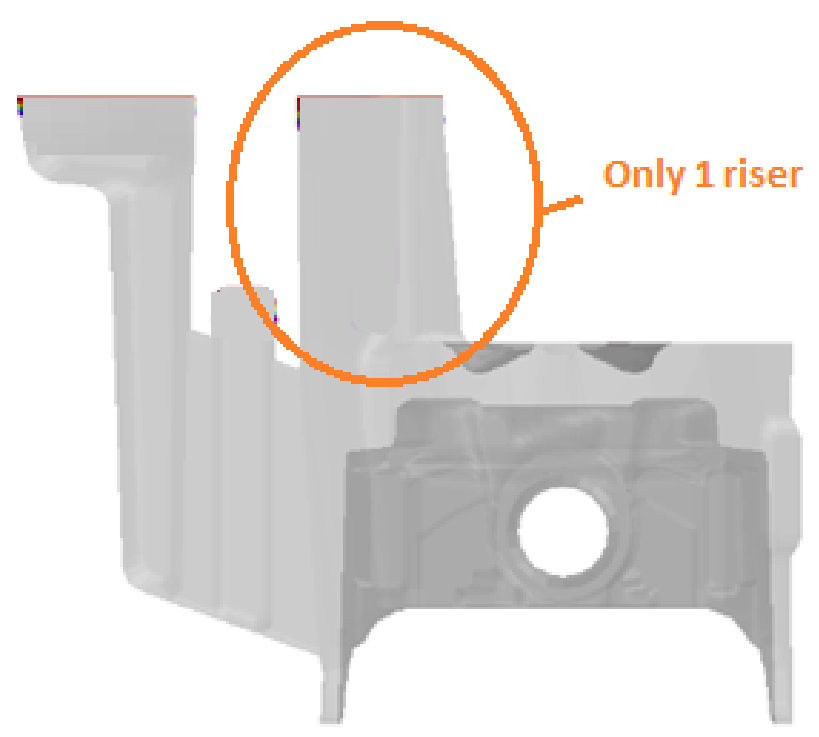

Figure 10 Piston riser 3D modification 


\section{Simulation with proposed modification}

Using the same process parameters, but with the change in the design, the simulation is run again and thus be able to detect with the change in the design eliminate the main defect [5].

The results are shown in Figure 11.

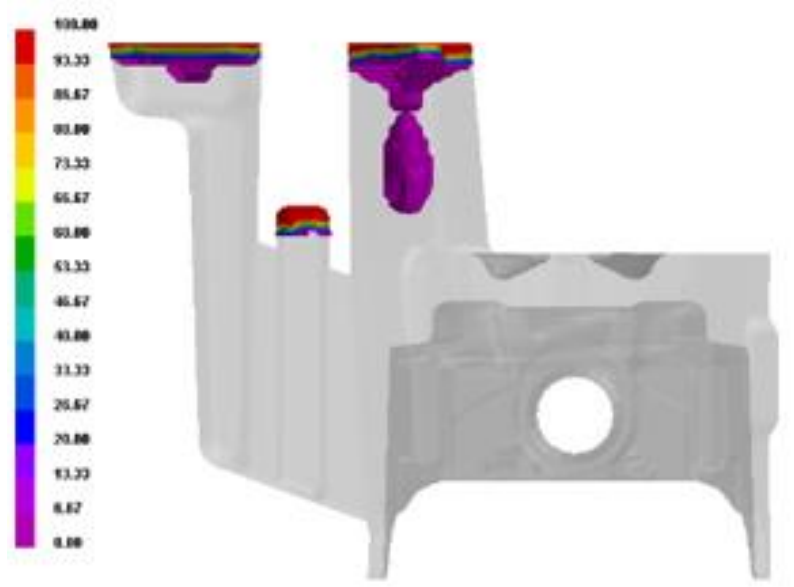

Figure 11 Simulation result with new riser

As can be seen in the simulation result, the defects disappear due to the change in the design of the piston feed during its casting process, so far it is satisfactory as the result is shown, eliminating the defects, but as previously done. , now the change must be made in physics and run a test on the floor to corroborate the result in the real process and demonstrate the reliability of the software in reverse.

The change in the mold and part is carried out in the company's workshop, eliminating the two central risers and leaving only one placed near the main power supply.

\section{Casting process results (modified)}

With the change made in physics based on the simulation and the CAD model, we proceed to program a run of 100 pistons on the floor to be able to take a significant sample that helps us to generate a panorama of correct piston conditions, with the same parameters of process but with the change in its design, the floor test is run as shown in Figure 12.

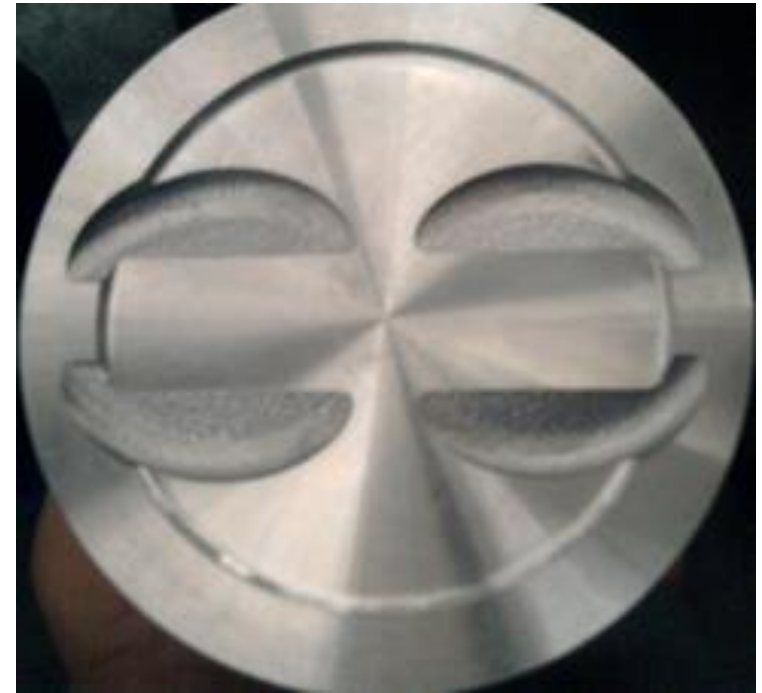

Figure 12 Piston free of imperfections

The piston can be seen that its main defect was eliminated within the main defects of the 100 piston run, therefore, it can be deduced so far that the software has had a high reliability. Therefore, stopping from the second stage is to carry out a larger run to corroborate the data and modifications.

Table 3 shows of the 100 test pistons which were the results and their defects.

\begin{tabular}{|l|r|}
\hline \multicolumn{1}{|c|}{ Description } & N. Pieces \\
\hline Good parts & 78 \\
\hline Pore in head & 5 \\
\hline Cold junction & 4 \\
\hline Gas & 10 \\
\hline Metallic inclusion & 3 \\
\hline
\end{tabular}

Table 3

Within this run it can be quickly said that its performance is $78 \%$, that is, $78 \%$ of the pieces produced were classified as "acceptable pieces", therefore, it is necessary to corroborate and compare with a larger run, the which will be established as part of the second stage of the Project.

\section{Conclusions}

It was possible to find a relationship between the software and the process on the floor, in tests considered as quick the result has been favorable, but a larger test has to be carried out and to be able to have the exact reliability of the software and to be able to make decisions in the future. I respect its use and application as part of the company process. 


\section{References}

Pistones Moresa S.A. de C.V. Estudio de mercado. Propuesta de proyecto 2021.

Método de las diferencias finitas; Transferencia de Calor; Manrique; 2da. Edición; 2002.

Amezcua Álvares Carlos; Notas del curso "Proceso de Fundición"; Academia de Ingeniería Mecánica; Celaya, Gto.; 2017

Vázquez Lasso Víctor H.; Curso: "Curso de entrenamiento en QuikCAST"; director general de Consultores en Conformado y Procesos de Manufactura S.A. de C.V.; Monterrey N.L.; 2020

Notas de fundición; Pistones Moresa S.A. de C.V, 2021. 